\title{
Identification and Description of Production Constraints of Main Food and Cash Crops in North Kordofan State
}

\author{
Ahmed M Murakah ${ }^{1 *}$ and Elkhalil Elnour Breima ${ }^{2}$ \\ ${ }^{1}$ Agricultural Research Corporation, Elobied Research Station, Sudan \\ ${ }^{2}$ Agriculrtural Corporation, Zalingei Research Station, Sudan
}

Submission: March 03, 2018; Published: June 26, 2018

"Corresponding author: Ahmed M Murakah, Agricultural Research Corporation, Elobied Research Station, Sudan, Email: amurakah@yahoo.com

\begin{abstract}
This study was carried out in Elkhwei locality of North kordofan state during 2012/2013 cropping season. The main objectives of the study are to identify production constraints of food and cash crops. Structured Questionnaires applied to collect primary data. The study applied multi-stage random sampling technique. Fifty household farmers were randomly selected. Descriptive statistics, linear regression analysis, (CobDouglas function) and linear programming (LP) were used to analyze data. Results of frequency distribution indicated that majority of farmers (78\%) Productive age was found to be between 40 -65 years. Results also founded that $60.7 \%$ of the farmers use local tools, while $22 \%$ and $1.3 \%$ use tractor and animal drawn implements respectively. Accordingly $77.9 \%$ using traditional methods of seeding, Linear regression results showed that land, labor and capital have significant different at five and one percent from zero level. This implies that the increase in output attributed to such factors of production. Linear programming results revealed that Dura, Sesame and Groundnut were optimized and gave SDG total gross margin of 562.6. The highest SDG gross margin (223) was obtained by sesame, followed with Dura (214.6 SDG) and groundnut with SDG gross margin 125.7.
\end{abstract}

Keywords: Constraints; Linear regression linear programming; Agriculture; North kordofan

\section{Introduction}

Sudan is one of the largest countries in Africa, and has a population of 39 million according to the recent census in 2008, of which $79 \%$ are rural Agriculture is the largest production sector, which provides livelihood for $75 \%$ of the population and contributes around $90 \%$ of export earnings. This sector has two main sub-sectors, irrigated sub-sector in some areas of the central clay plain and rain-fed one in many areas of the western and central parts of the country. Climatic zones are classified into desert in the northern part of the country to semi desert, arid and tropical in the southern part of the country. The desert, which is not suitable for cultivation, occupies $30 \%$ of the total area, while the arable land is estimated as 200 million feddans.

North Kordofan state is located between latitudes 11-16 N and longitudes 27-32 E. the state inhabited by different tribes of different origins and accordingly different livelihood sources and strategies exist. About 80 percent of the population in the state depends on agriculture as their main source of food and income. The farming systems in the area are predominantly rainfed, traditional, and operate with limited resources. They are characterized by the small size of holdings, being dependent on manual family labor, and using few or no external inputs such as fertilizers, chemicals or seeds. Farmers have poor access to information and relevant research results, and yields obtained are very low [1].

Types of crops in the state are closely related to soil type and moisture availability. Sandy soils are devoted mainly to millet (Dukhun) the stable food of the area and cash crops as sesame, groundnut, "Karkade" (roselle) and watermelon. Sorghum (Dura) is grown on clay and alluvial soils. Vegetables as okra, local type of cucumber (Tibish) and other vegetables are produced on small scale particularly on sites that receive runoff. Some households have own "Hashab" gardens for gum Arabic production. A large part of the holding is devoted to sorghum and millet the stable food of the households to ensure reasonable production which means food security [1].

Similar study found that in socio-economic characteristics the gender structure of farm households as referred to socially constructed roles, learned behaviors and expectations associated 
with females and males. It includes the ways in which those differences, whether real or perceived have been valued, used and relied upon to classify women and men and to assign roles and expectations to them [2].

Siddig [3] stated that farmers' age is one of the demographic characteristic which influences the quality of decision and his attitude toward accepting new ideas. On other hand farmer education in general can be defined as accumulation of knowledge and experience to prepare an individual farm $[3,4]$. The success of farming process and hence the amount the quality of output depend on perfect and timely conduction of the different farm practices which in turn depend on quality and quantities of inputs used. Among which, farm labor or agricultural machinery and traditional tools of cultivation. Also the application of the recommended improved cultural practices was found to be useful in various aspects [5]. The "tenure" is used to signify the relationship between tenant and land or as common law systems, to the legal regime in which land is owned by an individual. This respect all private owner are either its tenants or sub-tenants [6].

From above mentioned the main objective of this study to identify the socio-economic constrains that affect of food and cash crops production in Elkhwai locality.

\section{Material and Methods}

This study was carried out in Elkhwei locality of North Kordofan State during 2012, 2013 cropping season. Structured questionnaires used to collect primary data. Clustered random sample technique applied for 50 selected households. In addition qualitative data in form of group discussion and panel data were also collected. Descriptive statistics, regression model and linear programming were applied.

\section{Linear regression}

The general form of the equation is written as:

$$
Y=A X a 1 X b 2 X c 3 e u
$$

Where $Y=$ output (dependent variable) all activities dura, sesame, groundnut, millet in monetary term, $A=$ intercpt, $X 1=$ land in fedaan, $X 2$ = labour in man days, $X 3$ = capital in Sudanese genih SDG (independent variables) and $\mathrm{u}$ is the error term, $a, b, c$ are regression parameters. Then the transformed form is:

$$
L N Y=a \operatorname{In} X 1+b \operatorname{In} X 2+c \operatorname{In} X 3+u
$$

\section{Linear programming models}

The objective function: maximize $\mathrm{Z}$

$$
Z=a x 1+b \times 2+c \times 3+d x 4+e x 5
$$

Where $a, b, c, d, e$ are coefficients of objective function

The general formula of the inequalities:

$$
A x 1+B x 2+C x 3+D x 4+E x 5 \ldots \ldots \ldots . \leq H
$$

Where $A, B, C, D, E$ are the coefficients of constraints inequalities

\section{$H$ is the right hand side (RHS)}

Model for crops: By letting $X 1=$ Dura, $X 2=$ Sesame, $X 3$ = groundnut, $X 4=$ millet, then algebraic version of the model became:

$$
\operatorname{Max} Z=214.6 X 1+105.3 X 2+125.7 X 3+98.3 X 4
$$

Such that:

$$
1.39 X 1+0.57 X 2+0.65 X 3+0.8 X 4 \leq 3.41
$$$$
19.66 \times 1+11.89 \times 2+14.07 \times 3+12.92 \times 4 \leq 58.54
$$$$
83 X 1+31.8 X 2+34.19 X 3+16.6 X 4 \leq 174.66
$$

And: $X 1, X 2, X 3 \geq 0$

\section{Results and Discussion}

\section{Socio-economic characteristics of household farmers}

Frequency distribution showed that $78 \%$ of sampled households were male while $28 \%$ were female. Results revealed that most household's age were within the productive year group of 40 - 65. This highlighted that work with households which are relatively younger's, more productive and more likely to be able bodied and therefore provides labor for agricultural activities, (Table 1). Results indicated that $78 \%$ of the households' were exposed to some sort of education. This meant present of literate farmers in the study area indicates farmers' awareness and knowledge to cope with new agricultural technologies. Literate

\begin{tabular}{|c|c|c|c|c|c|}
\hline \multicolumn{2}{|c|}{ Socio-economic characteristic } & \multicolumn{2}{|c|}{ Technical packages } & \multicolumn{2}{|c|}{ Crops production problems } \\
\hline Item & $\%$ & Item & $\%$ & Item & $\%$ \\
\hline Gender & & \multicolumn{2}{|c|}{ land preparation } & \multicolumn{2}{|c|}{ Shifting area } \\
\hline Male & 78 & Local tools & 60.7 & Food crops & 46.7 \\
\hline Female & 22 & Tractor disc & 22 & Cash crops & 53.3 \\
\hline \multicolumn{2}{|c|}{ Age (years) } & Animal tract & 1.3 & \multicolumn{2}{|c|}{ Seed varieties } \\
\hline Less than 15 & 5.5 & Local + tractor disc & 16 & Available & 17.2 \\
\hline
\end{tabular}
farmers (84\%) in the study area equipped with additional local knowledge to cope with climate change and food insecurity than those who had no formal education (Table 2).

Table 1: Socio-economic characteristics, Land preparation and sowing date, Technical packages, land tenure type and crops production problems (Source: field survey 2013). 


\section{Agricultural Research \& Technology: Open Access Journal}

\begin{tabular}{|c|c|c|c|c|c|}
\hline $15-40$ & 31 & \multicolumn{2}{|c|}{ Way of cultivation seeds } & Not available & 82.8 \\
\hline $40-65$ & 45.5 & By hand & 78 & Credit & \\
\hline 65 and above & 18 & By tractor disc & 14.7 & Have credit & 16.7 \\
\hline \multicolumn{2}{|c|}{ Educational level } & Hand + tractor disc & 7.3 & No credit & 83.3 \\
\hline Illiterate & 22 & \multicolumn{2}{|c|}{ Varity of seed } & \multicolumn{2}{|c|}{ Pests and disease } \\
\hline Khalwa & 17.3 & Improved & 21.3 & Pests & 93.3 \\
\hline Primary & 30 & Local & 70.7 & Disease & 6,7 \\
\hline Secondary & 22.7 & Improved + local & 8 & \multicolumn{2}{|c|}{ Labor } \\
\hline University & 8 & \multicolumn{2}{|c|}{ Source of seeds } & Available & 43 \\
\hline \multicolumn{2}{|c|}{ Land preparation date } & Farm & 65 & Not available & 57 \\
\hline March & 4 & Market & 27 & crops price & \\
\hline April & 26 & Organization & 8 & High price & 22 \\
\hline May & 40 & \multicolumn{2}{|c|}{ Weeding method } & Low price & 78 \\
\hline June & 28 & By traditional tools & 90.7 & \multicolumn{2}{|c|}{ Extension service } \\
\hline July & 2 & By herbicides & 1.3 & Access & 21.2 \\
\hline \multicolumn{2}{|c|}{ Sowing date } & $\begin{array}{c}\text { Traditional+ } \\
\text { herbicides }\end{array}$ & 8 & Not access & 78.8 \\
\hline May & 6 & \multicolumn{2}{|c|}{ Way of threshing } & \multicolumn{2}{|c|}{ Land tenure } \\
\hline June & 68 & By hand & 65 & Own & 70 \\
\hline July & 24 & By harvester & 20 & Heritage & 12.7 \\
\hline \multirow[t]{3}{*}{ August } & 2 & Hand + harvester & 15 & Gift & 7.3 \\
\hline & & & & Rent & 8.7 \\
\hline & & & & Participation & 1.3 \\
\hline
\end{tabular}

Table 2: Average cultivated areas (feddan), production $(\mathrm{kg})$, productivity ( $\mathrm{kg} / \mathrm{feddan}$ ), value of production (SDG), labour (man days) and total cost of production.

\begin{tabular}{|c|c|c|c|c|}
\hline Crop & Dura & Sesame & Groundnut & Millet \\
\hline Area & 1.39 & 0.57 & 0.65 & 0.80 \\
\hline Production & 460.7 & 113.15 & 168 & 171.75 \\
\hline Productivity & 331.4 & 197.1 & 258 & 213 \\
\hline Mean production (SDG) & 297.6 & 137.2 & 159.9 & 114.9 \\
\hline Labor man days & 19.66 & 11.89 & 14.07 & 12.92 \\
\hline Production Cost (SDG) & 83 & 31.87 & 34.19 & 16.6 \\
\hline GM (SDG) & 214.6 & 105.3 & 125.7 & 98.3 \\
\hline
\end{tabular}

Where, $\mathrm{GM}=$ Gross margin, SDG= Sudanese Genih.

\section{Regression result}

Table 3 showed that the explanatory powers or the determination measures of the explanatory variables ( $\mathrm{R}$ square) was, $63 \%$ these coefficients mean that around $63 \%$ of the explained variations in the output is explained by the variables included in the equations. Moreover, the F-test of each equation indicates it s overall significance so, the estimated equations can be written as:

Table 3: Regression results

\begin{tabular}{|c|c|c|c|c|}
\hline Explanatory Variables & B & Standardized Coefficients (Beta) & T-value & Value of Level Significance \\
\hline (Constant) & 3.87 & - & 7.813 & 0.000 \\
\hline Land (feddan) & - & 0.285 & 2.452 & 0.018 \\
\hline Labour (man days) & - & 0.291 & 2.925 & 0.006 \\
\hline Capital (SDG) & - & 0.052 & 4.559 & 0.000 \\
\hline
\end{tabular}

$(\mathrm{R} 2=63 \%) \mathrm{R}$ square $\mathrm{F}=23.9$ Sample size $(50)$ 


$$
Y=3.87+10.285 \times 20.291 \times 30.052 u
$$

Or

$$
\operatorname{Lny}=3.87+0.285 \operatorname{In} X 1+0.29 X 2+0.52 \operatorname{In} X 3+u
$$

Land (feddan) influences the output by 28.5 with high significantly at 0.000 . This result indicated that, when land increase by $1 \%$ output increased by $28.5 \%$ in case consistently the others factors.

Labor (man days) influences the output by 29.1 with significantly at 0.018 . This result revealed that: when increasing the labor input by $1 \%$ increases output by $29.1 \%$ in case consistently the others factors.

Capital (SDG) influences the output by 5.2 with high significantly at 0.000 . This result revealed that: when increasing the capital input by $1 \%$ increases output by $5.2 \%$ in case consistently the others factors. From above mentioned Regression results reported that Land labor and capital were significant at five and one percent from zero level, respectively. R2 was 63\%. This implies that the increase in output attributed to such factors of production.

Table 4: linear programming tableau.

\begin{tabular}{|c|c|c|c|c|c|}
\hline Row Name & Dura (feddan) & Sesame (feddan) & g/nut (feddan) & Millet (feddan) & Right hands \\
\hline $\begin{array}{c}\text { Objective function } \\
\text { (SDG) }\end{array}$ & 214.6 & 105.3 & 125.7 & 98.3 & Maximize \\
\hline Land/feddan & 1.39 & 0.57 & 0.65 & 0.8 & $\leq 3.41$ \\
\hline Labour /man days & 19.66 & 11.89 & 14.07 & 12.92 & $\leq 58.54$ \\
\hline Capital/SDG & 83 & 31.87 & 34.19 & 16.6 & $\leq 174.66$ \\
\hline
\end{tabular}

Sample size (50)

Linear programming results showed that out of four crops, only three were optimized. The highest SDG gross margin (223)

\section{Linear programming result}

Table 4 revealed that, by the results of linear programming when the area that form the structure of the crops which achieve an attractive return is 1.39 feddan dura, 0.57 feddan sesame and 0.65 feddan groundnut and 0.8 Feddan millet and the rest of the space for other crops of the total area of 3feddan ideal. From that table four crops can be grown: Dura, sesame, groundnut and millet each of which has specified per feddan requirement for land, labour and capital. Production of (1.39) Dura requires 19.66 days and 83(SDG) capital cost, production of (0.57) sesame requires 11.89 days and 31.87(SDG) capital cost, production of (0.65) groundnut requires 14.07 days and 43.19(SDG) capital cost while production of (0.8) millet requires 12.92 days and 16.6(SDG) capital cost. A total of 3.41 (feddan), 58.54(days) and 174.66(SDG) are potentially available, being the amount providing by land, labour and capital respectively. The activity gross margins in the objective function are differ for each unit (feddan) of millet, groundnut while Dura and sesame are much more profitable though, with a gross margin of (214.6), (223.7) (SDG) respectively revealed that sesame and Dura was the most profitable one than groundnut and millet, and the total returns were 632.8 SDG. was obtained by sesame, followed with Dura (214.6 SDG) and groundnut with SDG gross margin 125.7 (Table 5).

Table 5: Optimal solution

\begin{tabular}{|c|c|c|c|c|}
\hline Crop Variety & Dura & Sesame & Groundnut & Millet \\
\hline $\begin{array}{c}\text { Optimal solution area } \\
\text { feddan will be added }\end{array}$ & 214.6 & 223 & 125.7 & 0 \\
\hline
\end{tabular}

\section{Conclusion}

The study concluded that land, labor, improved technical packages, extension services and capital are major limiting inputs to increasing crop production. This reported that Land labor and capital were significant at five and one percent from zero level, respectively. This implies that the increase in output attributed to such factors of production. Linear programming indicated that, cultivation of (sorghum, sesame, groundnut and millet)/feddan showed improvement of farmer's gross margin. From the above mentioned among four varieties Cultivation (sorghum, millet, groundnut and sesame) three crops (Dura, sesame and groundnut) were entered the optimal solution, this indicated that cultivation of (Dura, sesame and groundnut) was more profitable crop

combinations compared to millet. We recommend that improved research technologies and extension service should work together to enhance agricultural crop productivity and improve farmer's income.

\section{References}

1. Ibrahim EI (2013) Measuring the efficiency profile of crop production in traditional rainfed Sector of North Kordofan state, $\mathrm{PhD}$ Thesis, University of Khartoum, Sudan

2. World Bank (2001) Engendering Development Through Gender Equality in Rights, Resources, and Voice, World Bank Policy Research Report, World Bank and Oxford University, USA.

3. Siddig RA (1999) The Economics of Crop Production Under The Different Land Tenure System, M.Sc Thesis, Department of Agricultural Economic, Faculty of agriculture, University of Khartoum, Sudan. 
4. Ahmed AE (1996) Productivity and resources allocation efficiency of major field crops in the Gezira scheme, MSc thesis department of rural economy faculty of agriculture university Khartoum, Sudan

5. Eaton J, Dekle R, Kortum S (2007) Agricultural research system in the world.
6. Suleman M (1998) Sudan, Resources, Access, Violent Conflict, and identity, institute for African Alternative, London, United Kindum, Sudan.

\section{Your next submission with Juniper Publishers} will reach you the below assets

- Quality Editorial service

- Swift Peer Review

- Reprints availability

- E-prints Service

- Manuscript Podcast for convenient understanding

- Global attainment for your research

- Manuscript accessibility in different formats ( Pdf, E-pub, Full Text, Audio)

- Unceasing customer service

Track the below URL for one-step submission https://juniperpublishers.com/online-submission.php 